\title{
Distinctive Features of the Language and Style of the Yakut Heroic Epic Olonkho (Based on Olonkho 'Nyurgun Bootur the Impetuous' and 'Kulun Kullustuur the Recalcitrant')
}

\author{
Lina Mitrofanovna Gotovtseva', Nadezhda Ivanovna Danilova', Svetlana Dmitrievna Muhopleva', \\ Albina Mikhailovna Nikolayeva ${ }^{1}$, Alena Kirilovna Prokopeva ${ }^{2}$ and Munir Idelovich Karabaev ${ }^{3}$ \\ 'Institute for Humanities Research and indigenous Studies of the North Siberian \\ Branch of the Russian Academy of Sciences, Yakutsk, Russian Federation; \\ Limg.o@rambler.ru,divnain@mail.ru,muhlp.sve@mail.ru, albisams@rambler.ru \\ ${ }^{2}$ North-Eastern Federal University (NEFU), Yakutsk, Russian Federation; alenaki_hoo@mail.ru \\ ${ }^{3}$ Sterlitamak Multi-Disciplinary Professional College, Sterlitamak, Russian Federation; munir.karabaev@yandex.ru
}

\begin{abstract}
Background: The scientific article is devoted to studying language features of the Yakut heroic epic olonkho and to identifying the stylistic use of certain linguistic facts in the folklore texts of this genre. Methods: The aim of current research is to identify productive linguistic ways that form the style of Yakut olonkho and to study the specific features of the language of this work. This article seeks to determine the place of expressive means in creating figurative and semantic integrity in the olonkho. The authors of the paper have identified the main figures of speech, which are widely used in the text of the literary work, as well as have set their basic trailblazing functions. In addition, the authors provide a generalized description of other linguistic ways of the olonkho style organization. Findings: This article focuses on the use of linguistic tools to create the image of a bogatyr and the image of the native shore nature. Also, the phonetic and grammatical means of the olonkho style are described in detail. According to the authors, the love for eloquence is a factor in the genesis of such rich Yakut folklore. Olonkho excels as an uppermost example of the Yakut language artistry, and its language is recognized as one of the main indicators of the olonkho singularity. Improvements: The novelty of the proposed method consists in the fact that the study has identified the language means that created the figurativeness of the text and defined its stylistic feature.
\end{abstract}

Keywords: Epic Work, Language Means, Olonkho, Style, the Yakut Folklore, the Turkic Epic

\section{Introduction}

Folklore is an actual encyclopedia of poetic knowledge, giving a comprehensive view of the ideological and poetic wealth of its creative work. It holds a special place among other arts. Learning the language of folklore is one of the most important tasks of philology, without which it is impossible to solve many problems in the field of the fine literature language science, it is impossible to correctly understand and highlight the issue of the national character of a writer or a work.

The importance of studying the Turkic epic works is related to the fact that the epics of other peoples have survived in literary records and adaptations, and among the Turkic peoples there still exist 'live' epic genres performed by folk word painters. The Turkic heroic epic is presented

${ }^{*}$ Author for correspondence 
both as archaic samples (heroic tales-songs of the Turkic peoples of Siberia: Yakut, Shor, Altai), and as later forms of the heroic epic.

The study of the Turkic epic language to date has been noted with major achievements of both Russian and foreign specialists. Numerous works, devoted to the analysis of the language of the Turkic epics 'Alpamysh, 'Oguzname', ' Koblandy- Batyr', ' Kyor-ogly', ' Ural-Batyr', etc., have been published. The research of the language features of the Yakut heroic epic olonkho has been conducted in the traditions of the Turkic folkloric science, its foundation having been laid in the late XIX century.

The interest in the particular language of olonkho is based on the fact that this folklore genre, compared with mythology and ritual poetry, represents a higher level of the aesthetic attitude to the reality and of the oral tradition development ${ }^{\underline{1}}$.

Researchers are primarily interested in the artistic and figurative features of olonkho, i.e. storylines, images, composition, artistic devices; the issue of the epic tradition periodization is the special subject of the study. The olonkho studies on that front were initiated by a fundamental monograph of E.I. Ubryatova' 'Studies in the syntax of the Yakut language'. In the second part of this work, devoted to a complex sentence, a construction referred to as 'period' was analyzed for the first time as the main form of the olonkho syntactic constructions. E.I. Ubryatova indicated that this construction is also widely used in literary works in the terrain description, the appearance of a character, etc. She distinguished syntactic parallelism out of the many period forms as a special construction, characteristic of the folklore works. According to her, 'among many kinds of periods in the Yakut language, parallelism should be especially highlighted as the most common form of a complex sentence in the folk poetry writing language?

A great contribution to the olonkho language studies was made by P.A. Sleptsov, who regarded the oral folk arts of the people as one of the origins of the modern national literary language. He considered epic formulas, archaisms, and dialecticisms as distinctive language elements. In his view, the lexical-semantic features of the olonkho language were determined by the fact that in linguistic terms, the artistic means, the entire olonkho poetics ... is underpinned by the extensive use of vocabulary, lexical and phraseological resources, and the figurative (depictive) semantics of the epic language. The need for linguistic analysis of these epic works is also motivated by the fact that, in the unanimous opinion of experts and of the people themselves, the olonkho language and style represent the highest form of featured, refined, artistically organized oral poetic speech'

Olonkho is a heroic epic poetic work, created via the oral literary language. The researchers of the olonkho poetics underscore its inherent elevated style. Olonkho introduction solemnity, the heroic spirit of its deeds and of the bogatyrs' rhetoric, the description exaggerations by an olonkhosut are the olonkho extra-linguistic feature.

\section{Methodology}

For a comprehensive study of the olonkho language, a descriptive method has been used in the paper, as well as some elements of analysis and synthesis. Descriptive and historical methods have been used by the authors when collecting and cataloging, as well as systematizing the linguistic material. By applying the descriptive method, language units have been divided into categories and types. The historical approach in the study of the olonkho language and style has allowed showing the connection of this phenomenon with the language development history. In addition, the historical method allowed determining the correlation of some semantic phenomena with a particular period in the life of the native Yakut language speakers. When using the method of analysis, language material connotative signs were revealed. The results of the work can contribute to deepening the study of the epic folklore genres language. Some conclusions can be used in the study of historical grammar of the Turkic languages. The practical significance of this study lies in the fact that the work can be required in the preparation of general and specialized dictionaries; the article materials can be used in research work on the stylistics and semasiology of the Yakut and other Turkic languages.

\section{Results}

\subsection{Olonkho Expressiveness}

As is known, in linguistics, expressiveness as a speech (pragmatic) category is traditionally identified with expressivity ${ }^{\underline{4-7}}$. The connotative signs of expressiveness include emotional, evaluative, and intensely expressive components. The emotionality category deals with the expression of emotions and feelings, whereas the cat- 
egory of intensity deals with qualitative quantitative sense amplification; evaluativity expresses a subjective evaluation. In addition, researchers highlight figurativeness as a mandatory component of expressiveness. Figurativeness is the essence that causes both an emotional response and intensity (i.e., acts as an expressivity stimulant).

The expressive means create in the olonkho a symbolic figurative and semantic integrity, being in communication with each other and finding them in the same position.

Constant epithets are the main artistic tool in the olonkho text 'Nyurgun Bootur the Impetuous' ('Дьулуруйар Ньургун Боотур') (recorded by K.G.

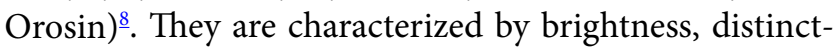
ness. They are created by an olonkhosut (a tale-teller, performing the Yakut epos olonkho) to highlight the most distinctive feature, quality of an object or a phenomenon. Epithets give the olonkhosut's speech solemnity, sublimity: а5ыс иилээх сађалаах, атааннах-мөнуөннээх аан ийэ дойду 'eight-banded, eight-edged slippery and hummocky primordial of the mother earth', авл yom, aлaha двиэ 'sacred fire, warm cozy home's. In olonkho 'the detailed description, amplification are often achieved by means of epithets enumerating various object or phenomenon features. They serve to refine, enhance and generalize the distinctive features of the depicted'? Usually it is the description of the local nature: уолан баранар уулаах, охтон баранар мастаах дойду 'evaporating with waters decreasing, with thinning trees falling', caтbыь манан халлаан, сандаБалаах мађан халлаан 'dismounted sky, most illustrious radiant sky', or

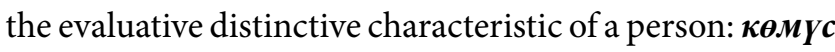
түөстээх күөрэгэй, алтан түөстээх далбарай 'silver-chested little lark, copper-chested little bird'.

In the olonkho text, there is a wide array of comparisons that with the help of an objective juxtaposition create a figurative picture of a particular epic phenomenon ${ }^{10}$. By means of SCs the olonkhosut highlights the most striking and significant features of objects and phenomena, in order to reveal their essence more fully and deeply. Figures for comparison come from the life itself, the nature, and the outside world. As the reference standards, the names of an animal, bird, tree, utensils are most commonly used, for example, am 'male horse', сылгы 'horse', таба 'deer', кус 'duck', туруйа 'heron', кыталык 'white crane', бальк 'fish', улар 'wood grouse', muиm 'larch', мас 'tree', amыйах 'birchbark water bucket', ox 'arrow', etc. Normally, set comparisons include the comparing component кypдyк 'as', дылы 'like', са5а 'the size of.... A human, their body, and appearance are described by comparing with objects of the nature - birds, trees, and celestial bodies - the sun, the moon, etc. Comparing young men to cranes: тоБус субан туруйа курдук уолаттар, comparing

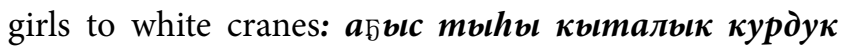
кыргытmap 'nine young men, like tall cranes, eight girls, like female white cranes', the image of the young is created; a bogatyr of the Underworld Timir Yiysta Khara (abaasy) is likened to the shadow of a larch on a moonlit night: ыйданатаађы тиит күлүгүн курдук суор хара киһи 'huge man as black as a raven, as tall as the shadow of a larch on a moonlit night'. To describe the bogatyr of the Middle World Kyun Erbiye, the following comparison is used: күн толонун курдук толонноох ньуурдаах, ьй килбиэнин курдук килбиэннээх сирэйдээх 'his face as the sun-disk, his forehead is like the full moon'. Comparing objects to орулуос кyс 'golden eye' is frequent. Combining with the lexical unit's кьıнаm, сbıмьıım, this set comparison conveys various attributes of an object or the intensity of an action. For example, Aŭbıы айма5ын аһыıтmaн аБаллым, орулуос кус сымы бopaxmus 'I brought from the food of the aiyy tribe a yellow grace, the size of a golden eye's egg'.

Comparisons are used for emotional and expressive assessment of objects, phenomena of the reality, both positive and negative: аан дойдуmа атыйахmaax yy курдук хамнаaта 'his home country began to shake like water in a trough; барбатах бальк минин курдук бадыьа-бүдуө дойду 'the country dark gray, like an undercooked fish soup'.

Comparative Set Comparisons (SCs) give a special colorfulness, figurativeness to speech.

When describing epic heroes, the exaggeration of appearance is used. Description of a bogatyr's appearance is as follows: [Уол] үрдүгэ - үрдүк тиити төргуY мутугунан холобурдаax 'the boy has grown as tall as

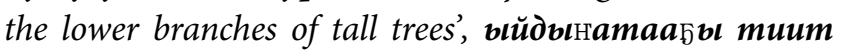
күлүгүн курдук суор хара киһи ... 'a huge man, black as a raven'.

Some hyperbolic SCs typically deliver an evaluative distinctive characteristic meaning, expressing the extreme intensity of an action: абааһь уола ... унуоргу mыı баһа сатарыар диэри ьллыьь турда 'abaasy's son ... was standing and singing so loudly that it was returning an echo at the tops of the trees on the opposite side of the field'. Among the exaggeration means, there is a separate group of phraseological units (FUs) of spatiotemporal and quantitative semantics: Мөлсүт Бөъө: ... 
көрөн баран чыпчылыйыах бэтэрээ өттугэр, этэн баран эуирийиэх бэтэрээ өттугэр кэлэ оьуста 'Melsyut Boege ... came back before looking at it, had time with an eye and hearing (about it), had time to draw in sоте air'; Харааннаабы выам бырдабьн курдук Үгүс дьон мустубут дойдута буолла... 'As mosquitoes in a dark starless night, this country seemed to him․ Unreal, grotesque hyperbolic character of the image gives special expressiveness to the FUs of this group.

In a series of figurative means in olonkho, metonymy holds a special place ${ }^{11}$. Usually this is designation of a human: yommaax xapaxmaa cyo5a 'for people with fiery eyes not to dare to look at him point-blank', оноолоох соннооьу кытта орооһон, бииллээх соннообу кымта билсэн 'will meet those wearing clothes with a cut behind, is recognized with those wearing dresses with waist', or an animal "

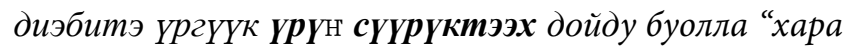
хальаһа" диэбитэ ханыл хара сүүрүктээх дойду буолла 'it seemed to him that the light snowdrifts (are lying), they turned out to be herds of white-haired horses; he thought that the mass of ice slurries (goes), it turned out to be herds of the white-haired, it turned out to be herds of cows - and so it turned out to be abundant herds and the abundant country'.

\subsection{Olonkho Emotionality}

In olonkho 'Kulun Kullustuur the Recalcitrant', many examples of expressivity phonetic amplification are to be found. This is mainly the terminal syllable vowel interchange - the vowel lengthening or its exchange with a diphthong $\frac{12}{}$. In a written form, the phonetic shell is retained at most; in particular, a change in the terminal syllable sound in order to enhance the conveyance of certain feelings and emotions: Куолайдата турарын куруһунун кербеккуен?! Бэлэстэтэ турдаххын да-а! 'Bah, how uproarious he is, how he is bawling and squalling!'. Apart from specific interjections that give olonkho an expressive shade, their phonetic formula provides

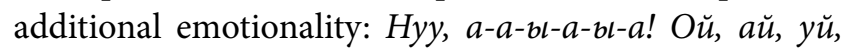
буйаккам; Муо-о, ой, муо, буйакам!; Мо-о, хор, хор!; Муо-а-йака-ам!; Tыıbй-тыıыйбын, аай-аайбын!; $М y-y$ ! Ой, буйакам!; Иэ-доммун, татай!; Ма-а-ьıа, хор, хор!; Бай, бай, да дуоба-ар!, etc. Such a change of the terminal vowel in order to enhance the expression is often observed in appeals: Ноколо-ор, тойон убайгыт Kulun Kullustuur the Recalcitrant maxcolбыm 'Well, guys, venerable Kulun Kullustuur is coming to you'; Чэйин, дођотто-ор! 'Ноколор!'; Хотуок, сэгэ-эр! - дииллэр 'My dear, darling, they say'; Ноко-о эрэ, нойончой 'Chappie, darling'13.

The appearance of the bogatyr Kulun Kullustuur the Recalcitrant is also described using the traditional means of olonkho. Here is a symbolic phrase that describes the epic hero-bogatyr from the aiyy tribe:

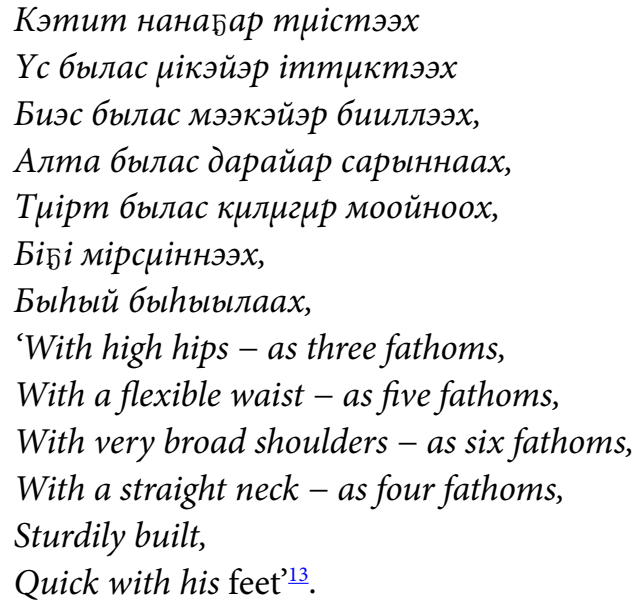

Here there are rhymes where, in case of coincidence of vowel sounds in the affixes, consonant sounds $\underline{\text { mэx }-}$ $\underline{\tau \ni x}$ are distinguished; and rhymes, where, in case of coincidence of consonant sounds in the affixes, vowel sounds, are differentiated ${ }^{14}:$ наах The rhymes prevail, where the same parts of speech with the same number of syllables are assonant - an adjective formed with the affix -лаах: тиістээх - іттнктээх - бииллээх - сарыннаах - моойноох - мірсніннээх быhыเıлаax ${ }^{15}$.

The initial assonance of the first words in a line creates an alliterative-assonant harmony, which also adds expressiveness, distinctiveness to the text:

Хара саһыл кыылы

Хайыта-тырыта бысталаан

Харах-хаас онорбут курдук

Халбалдыыгас

Хара кімнс хаастаах-харахтаах

'He has such mobile

Nielled silver eyebrows and eyes,

As if his eyebrows and eyes were coapted to him

From a flattened into two halves

Black fox ${ }^{16}$. 


\subsection{Functional-Semantic Features of the Olonkho Language}

In recent years, active research of the olonkho language functional-semantic features has been undertaken.

In the olonkho text 'Nyurgun Bootur the Impetuous', hortative constructions of two semantic types are presented:

1. Constructions with the meaning of the situation causation;

2. Constructions with the meaning of the object's activity causation.

The realization of this or that type of causative meaning depends, primarily, on the specifics of lexical semantics of a causative verb, which in turn determines particularities of the causative situation actants' roles ${ }^{17}$.

The first type of the constructions is formed mainly by the verbs of constructive or destructive physical effect on the object, and two actants: a causing subject in the form of the subjective case (N-1) and an object in the form of the accusative case $(\mathrm{N}-1 / 4)$. The specificity of this group of verbs is the following activity distribution among the participants of a causative situation: the subject with its active concreteness does not only cause the object, but rather creates, generates an event, in which the object is involved as a protagonist. In this case, the objects vary in their activity level in the occurrence of a new event. $\frac{10}{}$ In this type of a causative situation the object is not able to perform an act itself, it serves as kind of 'a tool, a way' to create an event or to form the overall situation.

In the formation of constructions of this semantic type, a causative verb without an affix of the causative voice is usually involved, and statements are built in terms of the model N-1, N-1/4 V caus. Formation of such a model is determined by the fact that a transitive verb used therein with the semantics of constructive or destructive physical effect on the object determines a noun in the accusative case: Ону мин Ньургун Боотуру...Анараа дойду албынын дьаныйарга анааммын айбытым 'I created this Nyurgun Bootur with the purpose to restrain cheaters of the otherworldly land'.

Constructions with the meaning of situation causation, that have the model $\mathrm{N}-1, \mathrm{~N}-1 / 4 \mathrm{~V}+$ caus., are also constructed with verbs with the affix of the causative voice: Килбиэннээх маңан сирэйгин киртитиэм, туналханнаах маңан ньуургун суһyктутуом 'I shall tarnish thy shining white face, mar thy lightful image'.
So-called dead verbal stems are also involved in forming constructions with the semantics of situation causation: Анараа дойду албыннарын алдьатарга анааммын айбытым 'You would have been destined to deal away with the gambits of the otherworldly land'; ТҮҮнүктээх Ньүкэн уөдэн түгэЂиттэн хоннорон хостоон таһаaрдың 'You liberated and pulled us out of the moldy dungeon'. Constructions with the meaning of situation causation often form a three-actantial model $\mathrm{N}-1, \mathrm{~N}-1 / 4 \mathrm{~N}-7 \mathrm{~V}$. The actant N-7, normally executed through the affix of the ablative case, has the meaning of a causation means ${ }^{\frac{18}{}}$.

\subsection{Constructions with the Meaning of the Object's Activity Causation}

Next causation semantic type is formed by constructions with the meaning of the object's activity causation that have the following typical semantics: the causer makes an active (usually animate) object either performs certain actions or deeds, or contributes to changing the psychophysical condition of the object. The hortative constructions of this semantic type are divided into two subtypes: a) constructions formed by the verbs of motion; b) construction with the verbs of forming an emotional state or bringing into it $\frac{19}{}$.

In the olonkho text, verbs with the semantics of an object's placing, spatial movement (бaaŭ - 'tether', бырах - 'throw', mahaар - 'take out', киллэр - 'bring in', олорт 'seat', xocmoo - 'pull out') are involved in the first subtype. The construction in this case contains an additional actant, and is based on the model: N-1, N-1/4 N-3 V=, where $\mathrm{N}-3$ is the actant-localizer of spatial movement: Уоллаах кызыстары, аттары, таңастары-саптары барытын быльттын урдүгэр олотто да, туох да бокуойа суох илдьэ барда 'He seated the boy and the girl together with the horse, clothing, munitions on a cloud and rode without a backward glance; Тойон аас сэргэ巨五 аттарын тумул хайа саха туора баайан кэбистилэр 'To the main tethering post they tethered their horses like a mountain cape'; Балтын ... атын самыьытыгар бырахта 'He threw his sister on the rump of his horse.'

Constructions with the semantics of the object movement can have the model N-1, N-1/4 V+caus.: Тимup атара кутуругун адаарытчы тардан кэбистэ 'Не unfolded his tail from iron sticks to its full width; Дьахтар

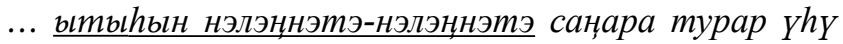


'Woman ... spreading her palms, is standing and speaking'. This model will be available in case the object is partitive, i.e. belongs to the subject or is immediately physically subordinated to it: кутуругун 'his tail', сирэйин 'his/ her face', абаahı бyхатыььрын 'of the bogatyr abasy', ыстыһын 'her palms'.

In constructions with the semantics of forming an emotional state or bringing into it, the meaning of causation is that the cause is either trying to bring an object to a psychological (psychophysical) condition (аралдььы - 'reassure', кuhuргэm - 'initiate self-praise, extol', cohym - 'scare, take by surprise', yockym - 'soothe, comfort', etc.) or the causer's activity (some attributes, deeds) provokes a psychological state in the object (дыулаm - 'scare', кblblhblpm - 'anger, annoy', etc.). More frequently, a human acts as an object, but an animal can also be in this role. Constructions with the verbs of the psychological condition causation in the olonkho text are built to the model N-1, N-1/4 V+caus, which requires the presence of a verb inflected with the causative affix: Хa, эһиги холоон да бухатыьыры киһиргэтэр эбиккит! 'Hиh, уои are extolling such a feeble bogatyr!'; Дьэ, долор, соһyтаннын кызайарын кыайдың 'Well, my friend, having taken me by surprise, you have undoubtedly won'.

Hortative constructions with expressive meaning are often built to the model N-1, N-3 V+caus., where N-3 is the position of an additional actant towards which a movement is directed: Холбороц ма5ан хочотун ортотугар хомуру тэбиннэрэн киирдэ 'Rapidly juтреd out ahorse into the middle of a pristine, serene valley'; Дьиэтин диэки уурдаран тағыста 'Rode swiftly towards the house'. As can be seen from the above examples, the actant N-3 has a diverse range of linguistic expression: this is the dative case-form of an auxiliary noun, a combination of a noun with a postposition ${ }^{20}$.

The olonkho text emotive space is extensively filled with the use of onomatopoeic and figurative verbs. In this case, in the model N-1, N-7 V+caus, the actant's N-7 position can be occupied with an instrumental case form, uncharacteristic of the model form, as in the following example: Кур мууһунан уhутатта, хара буорунан uhэx тэптэрдэ, ириэнэх маһь иэн иңиирин курдук илби тэптэрдэ 'Began to exhale icy clods, began to throw black soil around, tore young trees to pieces as the dorsal tendon'. By the standard, in the above construction, the causation object must be in the accusative case form and fill the position of actant $\mathrm{N}-1 / 4^{10}$.

\section{Discussion}

Thus, the semantic structure of causative constructions is formed by verbs of a relevant content, and features of the actants' roles in them. The use of onomatopoeic, figurative verbs and analytical verbal forms of hortative constructions allows achieving maximum picturesqueness of a depicted picture and of the emotional impact scale?

To communicate the extra-linguistic features, an olonkhosut uses a special syntax of speech ${ }^{21}$. Sentences in heroic epics have a specific structure. The authors have reviewed the types of Complex Sentences (CSs) in the olonkhos 'Nyurgun Bootur the Impetuous' by P.A. Oiunsky and 'Kulun Kullustuur the Recalcitrant' by I.G. Timofeev-Teploukhov.

The olonkho style tends to use synthetic and synthetic-analytical types of CSs. Thus, the synthetic type of CSs in 'Nurgun Bootur the Impetuous' is expressed at $91.1 \%$, in 'Kulun Kullustuur the Recalcitrant' at $66.7 \%$, and the synthetic-analytical type in 'Nyurgun Bootur the Impetuous' is expressed at $8.9 \%$, in 'Kulun Kullustuur the Recalcitrant' at $33.3 \%$. It is especially worth noting that the analytical type of CSs is not used in the olonkho at all, as this type of communication is contrary to the integral, coherent perception of epic works. The analytical type of communication, that expresses a contrasting relationship between events, is alien to the main form of sentences in the olonkho - period.

The olonkho language analysis shows that the texts of works are dominated by the use of attributive (29.4\% in 'Kulun Kullustuur the Recalcitrant' and 41.2\% in 'Nyurgun Bootur the Impetuous'), conditional (22.1\% in 'Nyurgun Bootur the Impetuous' and 20.2\% in 'Kulun Kullustuur the Recalcitrant'), temporal (17.6\% in 'Nyurgun Bootur the Impetuous' and $6.3 \%$ in 'Kulun Kullustuur the Recalcitrant') and causal (8.1\% in 'Nyurgun Bootur the Impetuous' and $11.8 \%$ in '21') Dependent Subordinate Units (DSUs) of CSs. Using the above DSUs can be called stylistic markers (characteristic features) of using CSs in the olonkho.

Special picturesqueness, expressiveness, rich inner form of the Yakut speech has been noted by many researchers ${ }^{22}$.

N.A. Vitashevsky ${ }^{20}$ writes: 'The Yakuts are capable of strong mental movements and are able to express their feelings in a sonorous impromptu. This ability and this skill are in close relation with the oratorical gift noticed in 
the Yakuts. The Yakuts have a special color of speech; they are able to enthrall the audience'.

It is the love for eloquence that is a factor in the genesis of such ample Yakut folklore. Olonkho excels as the uppermost example of the Yakut language artistry. Olonkho 'Nyurgun Bootur the Impetuous' and olonkho 'Kulun Kullustuur the Recalcitrant', in their storyline and content, their distinctive style, are undoubtedly some of the unique works of the oral tradition. They are abundant in vivid, expressive phraseological units and other set expressions that provide emotional, poetic speech ${ }^{23}$.

\section{Conclusion}

Thus, the authors have comprehensively studied the singularity of the language and style of the Yakut epic olonkho. Nevertheless, some questions have remained undetermined concerning the issue of studying folklore texts. In the future, the authors expect to undertake a further in-depth study of the epic folklore onomastic space.

\section{References}

1. Ergis G. Essays on Yakut folklore. Bichik: Yakutsk; 2008. p. 400.

2. Ubryatova E. Studies in the syntax of the Yakut language. Complex sentence. Book II. Nauka: Novosibirsk; 1976.

3. Sleptsov P. The Yakut language. Formation and development of national standards. Nauka: Novosibirsk; 1990.

4. Fedoruk EG. On expressiveness and emotionality in the language. In: Collection of articles on linguistics. Moscow; 1958. p. 103-5.

5. Arnold I. Interpretation of a literary text: the types of extensions and problems expressivity. In: Expressive means of the English language. Collection of scientific papers of Hertsen Leningrad State Pedagogic Institute. Leningrad; 1975. p. 40-52.

6. Nikolaeva A. Means of expressing expressivity in the Yakut language. Nauka: Novosibirsk; 2014.

7. Teliya V. Expressiveness as a manifestation of the subjective factor in the language. The Human Factor in the Language: Language Expressive Mechanisms. Nauka: Moscow; 1991. p. $110-8$.

8. Orosin K. Nyurgun bootur the impetus. Ergis GU editors. Yakut Book Publisher: Yakutsk; 1947.

9. Romanova L. AE Kulakovskii and his contemporaries. Nauka: Novosibirsk; 2002.

10. Dolinina I. Reflexivity and causativity (categorical semantics of reflexive constructions correlated with causative constructions). In: The theory of functional grammar: Personal Voice. Nauka: St-Petersburg; 1991. p. 328-45.

11. Sleptsov P. Linguo-folkloristics: problems and challenges. Folklore heritage of the peoples of Siberia and the Far East. Yakutsk Scientific Center of RAS SB: Yakutsk; 1991. p. 95-102.

12. Dyachkovsky $\mathrm{N}$ editor. On some emotional and evaluative affixes in the Yakut language. The Yakut language: vocabulary, grammar. Collection of scientific papers. Yakutsk State University Press: Yakutsk; 1993. p. 103-35.

13. Teploukhov IT. Kulun kullustuur the recalcitrant. Nauka: Moscow; 1995.

14. Abdullina G, Ishkildina Z, Karabaev M, Samsitova L, Fayzullina L. Morphonological phenomena in derivation process (as exemplified by the bashkir language). Indian Journal of Science and Technology. 2016 Sep; 9(36):1-7.

15. Vasiliev G. Yakut versification. Yakut Book Publisher: Yakutsk; 1965.

16. Dyachkovskaia M. Verse-forming elements in the works of the Yakut oral tradition. In: Folklore and Modern Culture. Yakutsk Scientific Center of RAS SB: Yakutsk; 1991. p. 1402.

17. Korkina E. Moods in the Yakut language. Nauka: Moscow; 1970.

18. Oiunskiy PA. Nyurgun bootur the impetus. Yakutsk: IGI AS RS (Ya); 2003. p. 565.

19. Bukharova G. Bashkir folk epos "Ural-Batyr": cognitivediscursive and conceptual analysis in Phylology $[\mathrm{PhD}$ thesis]. Ufa, Bashkir State University; 2002.

20. Vitashevsky N. Materials for the study of the Yakut folk language arts. Yakutsk; 1948.

21. Prokopieva A. Stylistic use of complex sentences in olonkho (as exemplified by Nyurgun bootur the impetus of Oiunskiy PA and Kulun Kullustuur the recalcitrant of Timofeev-Teploukhov IG) In: The Yakut language: history, development, functioning. Proceedings of the scientific conference devoted to the 100 anniversary of the honored. Scientist YASSR, turkologist Ubryatova EI and the 95th anniversary of well-known Turkologist, Mongolist Nadelyaeva VM. Yakutsk; 2008. p. 160-5.

22. Gotovtseva L. Phraseological synonyms in the epic olonkho by Timofeev-Teploukhov IG Kulun Kullustuur the recalcitrant. Philological Sciences. Issues of Theory and Practice. Tambov. 2013; 11-2(29):35-8.

23. Gotovtseva L. Stylistic functions of phraseological units in the text of olonkho by Orosin KG Nyurgun bootur the impetus. Proceedings of All-Russian Scientific-Practical Conference of Folklore and literature of the peoples of Siberia: tradition and innovation. Yakutsk; 2010. p. 176-82. 